\title{
Control of cockchafer Melolontha spp. grubs - a review of methods
}

\section{Danuta Woreta}

Forest Research Institute, Department of Forest Protection, Sękocin Stary, Braci Leśnej 3, 05-090 Raszyn, Poland, phone: 4822 7150551, fax: 22 7150557, e-mail: D.Woreta@ibles.waw.pl

\section{Abstract}

The paper presents a review of information on control measures used to prevent damages due to cockchafer Melolontha spp. grubs in European countries including Poland. There are described the methods used at times when mechanical and chemical treatments were applied as well as those under advanced research. In the past, cockchafer grubs were manually removed from plowed soils. Later on, chemical pest control commenced in plant protection practice, and a range of insecticides were either spotted directly onto plants or applied into planting rows, otherwise an entire planting area was treated. In that case, powder or granular insecticide formulations were mixed with upper soil layers, but liquid insecticides were poured into the soil around seedlings. The active substance of initial plant protection products used in Poland to control cockchafer grubs was lindane (organochlorine neurotoxin), which showed pretty high efficacy. Nevertheless, organochlorine products must have been withdrawn from the market and less damaging to the environment pesticides (organophosphates and carbamates) were recommended for use in forest protection against cockchafer grubs. As a result of progressive restrictions concerning application of chemicals into forest environment, alternate solutions have been sought, e.g. biological methods of cockchafer grub control have been tested. Up to date studies showed insecticidal properties of bacteria, fungi and nematodes. However, even though the knowledge and awareness of practitioners have raised with time, the problem of cockchafer grub populations damaging forest crops has not yet been solved and seems to be more and more difficult to overcome.

\section{KeY WORDS}

Melolontha spp, insecticides, biological and mechanical control means, Baeuveria brongniartii, Steinernematidae, Heterorhabditis

\section{INTRODUCTION}

The methods of cockchafer control have ever since been of interest of foresters due to substantial harmfulness of these insects, and especially their larval stages. Cockchafer larvae (grubs) feed on the roots of forest trees and shrubs and under certain conditions they may cause sig- nificant damage by reducing growth and even killing the plants. Long-term soil infestation with Melolontha spp. cockchafer grubs intensely feeding on young tree roots can drastically hold back forest regeneration in infested areas. Grub related damage is associated with the duration of cockchafer larva development in the soil, which under European climatic conditions usually lasts for 3 
years. The older the larvae become the more voracious appetite they show. Older grubs are more resistant to environmental factors, and therefore they are more difficult to control. In some Poland's regions adult cockchafers swarm every year and then different larval instars (L1, L2 and L3) occur in the soil. Grub control methods including those preventive, mechanical and biological were commonly applied in Poland already before the $2^{\text {nd }}$ World War (Woreta 1997). After the war, there were afforested vast areas of wastelands and low productive post-agricultural lands, and these were often heavily infested by cockchafer grubs (Woreta and Skrzecz 1996). In the 1950 's, chemical pesticides were introduced into forest protection practice. Insecticides recommended for control of root eating pest insects combated cockchafer grubs for some time. In the period of 1980-1993, the ,cockchafer problem” was perceived as minor and concerned mainly forest nurseries and undersized reforested areas (Woreta 1994). However, due to environmental and public health concerns, the use of chemical control means has been gradually reduced or brought to an end, which has had an effect on the fact that cockchafer numbers started increasing all over again and now pose a considerable threat to forest crops.

\section{Mechanical and biological measures USED IN EARLIER TIMES}

In the pre-industrialized era, the control of elevated cockchafer grub numbers negatively affecting various crops was a difficult and often unsuccessful undertaking. The main mechanism was to collect and kill the grubs during soil cultivation activities conducted when establishing a forest nursery or plantation (BB. 1892). Another method was based on attempts to lure cockchafer grubs into trap holes dug in the soil around- or in planting rows, which were filled with manure and covered with earth (Badeni 1894). The traps were checked once in a while to collect and eradicate captured grubs. At the end of the1800s, an appealing method was used by Jan Wospiel, a land owner who successfully employed domestic pigs to devour on cockchafer grubs destroying his crops (Wospiel 1895).

The possibility of using the pathogenic fungus Baeuveria brongniartii (Sacc.) Petch. to combat the cockchafer was first described by Leopold le Moult in the early 1880 s. The author noted that under natural conditions, this fungus (then - Beauveria densa Pic.) infected all the developmental stages of the pest. Subsequently, large-scale field trials on fungus effects were conducted throughout France (BB.1892). Some of the results obtained were promising enough to start recommending B. brongniartii as a means for cockchafer control. Only a few years later, within an area of present Polish land, there were known modes of infecting both cockchafer adults and larvae with $B$. brongniartii (BB. 1892; Remiszewski 1899). On the other hand, however, a few trials performed at that time showed no positive results (Wospiel 1895; Janeczko 1906). An attempt to control cockchafer grubs with $B$. brongniartii was once more made by Karpiński in the years 1934-1935 (Karpiński 1950). Under laboratory conditions, all cockchafer (Melolontha melolontha and Melolontha hippocastani) developmental stages were infected with $B$. brongniartii spores. At the same time, under field conditions, there were carried out trials on the effect of B. brongniartii powdered cultures (grown on potato substrate and then mixed with talcum) dusted onto swarming cockchafer beetles. The degree of fungal infection observed in cockchafer grubs was not sufficient, and the reduction of adult numbers was only by $20 \%$. In general, the studies conducted at that time, on a number of aspects connected with employment $B$. brongniartii to combat the cockchafer showed ambiguous results and gave no basis for recommending the fungus for use in forest protection practice.

Other methods applied in the past to decrease damage due to cockchafer feeding included utilization of plant derived substances. In Poland, this possibility was noted among others, by Różyński (1926). The author observed that different species of plants are susceptible to cockchafer damage to different extents. The roots of some plants were eagerly eaten by the grubs, whereas those of other plants were visibly rejected. The lack of feeding marks was observed on the roots of buckwheat (Fagopyrum sagitattum Gilib.), black alder (Alnus glutinosa Gaertn.), broom (Cytisus scoparius L.), largeleaved lupine (Lupinus polyphyllus L.), white alder (Alnus rhombifolia Nutt.) and black locust (Robinia pseudoacacia L.). The author applied this knowledge in further studies, the results of which showed that buckwheat sown into the soil (even heavily infested by the grubs) effectively chases the pest away. Interesting results were 
obtained from one greatly grub threatened area, where $6-7$ years old Scots pine stand (including stripes with then $8-9$ years old birch) was completely damaged due to cockchafer grub feeding. The tree stand was removed and buckwheat was sown within this area. Next year, the area was reforested with Scots pine, and this time tree seedlings were not damaged by the grubs. Above and beyond, Różyński (1926) recommended planting black alder trees in forest nurseries established on fertile soils and white alder - in those established on poor sites. The author believed that especially in large, open fields forest nurseries, there should be set up stripes of planted alder species. Beneficial effects of buckwheat on reduction of damage due cockchafer feeding in Scots pine reforested areas was also observed by Satkowski (1899). Later on, there was shown that a wild buckwheat species Fagopyrum tataricum Goertn. also indicated repellent properties against cockchafer grubs (Ułatowicz 1932). Studies carried out in the second half of the $20^{\text {th }}$ century, confirmed that cockchafer grubs avoid buckwheat roots, first of all because of their unattractive taste caused by high tannin contents. Furthermore, buckwheat is toxic for the grubs since tannins injure their guts. Consequently, cockchafer females do not find the areas sown with buckwheat attractive for laying eggs (Hersy 1986; Harborne 1997).

\section{COCKChAFER CONTROL MEANS UTILIZED FROM THE 1950S AND NEW ONES UNDER DEVELOPMENT}

\section{Chemical means}

Chemical insecticides to protect crops were commonly applied in the 1940s, especially after the $2^{\text {nd }}$ World War. One of these was DDT (dichlorodiphenyltrichloroethane) - synthesized in 1874. Its insecticidal action was discovered in 1939 by a Swiss chemist Paul Müller, who later received the 1948 Nobel prize for his discovery and its use as ,a contact poison against many arthropods” (Malinowski 2003). Just then, DDT seemed to be a solution for all pest insect problems all over the world. In Poland's forest protection practice, ,first generation” insecticides with highly toxic compounds (organochlorides, e.g. lindane - HCH or chlordane) were used to control cockchafer grubs. Lindane was applied as powder formulation and its efficacy depended on the rates used, given that too much of the insecticide damaged treated plants (Sierpiński 1975). Different tree species showed different levels of specific resistance to insecticide treatment damage. Most susceptible were oak and larch trees, whereas Scots pine trees were relatively most resistant. In the years 1952-1955, there was carried out a study on efficacy of lindane treatments with the aim to determine sufficient insecticide rates and effective modes of application (Schnaider and Karlikowski 1953). It was shown that dipping the roots of Scots pine seedlings in a paste made of water, humus and lindane $(\mathrm{HCH})$ preparation could considerably limit seedling die-back due to grub feeding. Preparation HCH-Verindal applied at a rate $1.8 \mathrm{~g}$ per seedling gave satisfactory results. Good results were also obtained when planted tree seedlings were treated with chlordane emulsion. Application of $\mathrm{HCH}-$ Verindal at a rate $200 \mathrm{~kg} / \mathrm{ha}$ onto the soil surface and then thorough mixing with soil upper layers $(30 \mathrm{~cm}$ deep) visibly limited grub damage in hybrid black poplar plantation. A study on efficacy of organochloride preparation Intox 8 carried out by Dominik (1958) showed that soil treatments at a rate $2 \mathrm{~kg} /$ are performed in the summer and repeated next year at a rate $4 \mathrm{~kg} /$ are sufficiently protected tree seedlings against feeding of 2-year-old grubs. Sierpiński (1963) studied the effect of $\mathrm{HCH}$ treatment timing (spring or fall) on grub control effectiveness. The results showed that both application timings were equally useful. Based on the results of the above studies, the procedure of chemical grub control was elaborated, and plant protection products based on lindane as an active substance, such as: Bentox, Owadziak, Pędraczak, Verinedal and Intox were recommended for use in reforested areas threatened by large grub populations. The insecticides maintained their properties in the soil for 2-3 years. The treatments were most effective against L1 and L2 larval instars (Dominik 1953). Insecticide rate and mode of application depended on the area treated. The areas designated for forest nurseries, new plantations or afforestation of post-agricultural lands were treated as the whole at a rate $150-200 \mathrm{~kg} / \mathrm{ha}$. Reforested areas were treated with insecticides at points of tree planting. Preventive treatments of already established young stands against cockchafer grubs were performed with liquid insecticide preparations (Śliwa 1993). However, it was gradually revealed that organochlorides kill not only target pests but also their natural enemies. Before long, it was published that DDT accumulated in 
soil and water, and its use was a threat to both wildlife and humans. A worldwide ban (including Poland) on its use in plant protection was announced in the 1970s (Malinowski 2003).

Once organochlorides had been withdrawn from the market, new, more environment-friendly insecticides were introduced into Poland's forestry practice for plant protection against root feeding pest insects: organophosphates and carbamates (Głowacka 1996). The following plant protection products containing organophosphates were recommended: Diazinon 10 G, Basudin $10 \mathrm{G}$, Counter $5 \mathrm{G}$ (granular formulations), Dursban 480 EC and Pyrinex 480 EC (liquid). The products with carbamates as active substances were: Furadan 5 GR, Diafuran 5 GR and Marshal suSCon 10 CG (granular formulation). New generation insecticides were applied onto grub threatened areas either at some points or into planting rows. From the beginning of the 1990s, in Poland and other European countries, there was observed gradually increasing damage due to Mellothonta spp. grubs in forest nurseries and reforested/afforested areas (Woreta 1999). In Poland, studies on efficacy of new generation insecticides against cockchafer grubs were carried out in 2006-2008 (Malinowski 2009). Different plant protection products were tested: Regent 200 SC (phenylpyrazole chemical family), Apacz 50 WG (neonicotinoid - clothianidin) and Mospilan 20 SP (acetamipryd). In these trials, Scots pine seedlings with the roots covered with growing medium (obtained from a container nursery) were dipped in water emulsion of a given product for a few minutes. The results showed that the treatments protected the seedlings even against the most voracious larval instars $\left(3^{\text {rd }}\right)$. Analogous effects were observed in treated pine seedlings obtained from a forest nursery growing seedlings in open fields.

In recent years, due to environment al concerns, the European Parliament has adopted new law on plant protection products (e.g. Regulation(EC) No 1107/2009 of the European Parliament and of the Council of 21 October 2009), which resulted in the withdrawal of almost all soil insecticides from the market. In 2009-2011, in Poland only liquid plant protection products (Dursban $480 \mathrm{EC}$, Pyrinex Extra 480 EC and Owadofos Extra 480 EC) were authorized for use exclusively in forest nurseries. The treatments with the use of 2.5-5 1 product/450-600 1 water/ha were allowed before the vegetation season, and 2.5-5 1 product/600-1000 1 water/ha at some point in the vegetation season (Głowacka 2010, 2011, 2012). At the same time, granular products which were formerly used for the protection of nurseries and young stands against root eating pest insects were placed on the list of hazardous insecticides, prepared Forest Stewardship Council (FSC). Seven million hectares of Poland's managed forests have been up to date certified by FSC (number 5 in the world, after e.g. Canada, USA or Sweden).

Now, following the EU's regulations on pesticide use and FSC requirements, in Poland there have been banned all soil pesticides and consequently no chemical plant protection product is authorized for use against cockchafer grubs (Głowacka 2014). At the same time, since the 1990s, grub numbers in forests have been gradually increasing in the areas of western and central Europe (Woreta 1995; Zelger 1996; Brenner and Keller 1996; Strasser and Schinner 1996). On the whole, no other than chemical grub control means has been so far successfully applied in Poland's forestry, while the losses due to grub feeding have become considerably high, e.g. roughly 7.5 million Euro in 2006 (Malinowski 2007). Excluding chemical insect control means from forest protection practice resulted in attempts to decrease cockchafer numbers through eradication of manually collected adult beetles from shaken trees, as done 100 years ago (Woreta 2008).

\section{Non-chemical means}

Mechanical methods of cockchafer grub control applied e.g. in Germany, refer back to those used in the past. These are based on soil tilling and eradication of exposed grubs. In soils heavily infested by the grubs, there is recommended repeated tillage - several times during the vegetation season (Fröschle 1994). Rotary cultivators are most effective tools for soil treatments carried out at the depth $15-20 \mathrm{~cm}$ in the period of June -August, after cockchafer $1^{\text {st }}$ instar larvae hatching. In general, the best results have been obtained when tillage was performed on moist and warm soils with L1 and L2 grubs. The effectiveness of grub control with the use of the above method was estimated to $60 \%-90 \%$ (Strasser and Schinner 1996). Taking into account contemporary requirements on soil cultivation, preventive treatments and mechanical means applied against cockchafer grubs can give insufficient effects (Fröschle 1994). There exist numerous factors limiting possibilities to apply tillage 
treatments in cultivation of forest soils, and these are mainly associated with land characteristics, e.g. water retention areas, sandy soil sites or dense vegetation areas, such as forest nurseries or newly reforested areas. In 1995-1999, within an area of several forest districts in Poland, there were carried out trials on mechanical eradication of cockchafer grubs on post-agricultural lands designated for afforestation. In most cases, a disc plough was used for soil cultivation down to $15-20 \mathrm{~cm}$ depth. Soil treatments repeated 3-5 times were effective in reduction of cockchafer population numbers to a level safe for future forest stands (Malinowski et al. 2001).

The findings on cockchafer food preferences published by Rożyński (1926) encouraged further Polish studies on grub feeding repellents. In the years 1995-1999, at some stage of 20-year-long cockchafer outbreak, there was carried out a study on the effect of buckwheat plants on grub vitality (Malinowski et al. 2001). The results obtained confirmed considerable reduction of grub population numbers already during one vegetation season of buckwheat cultivation. Above and beyond, there was also tested grub development on the roots of different forest tree species (Woreta and Sukowata 2014). The observations were carried out on L1, L2, and L3 cockchafer larvae which were fed on the roots of tree seedlings of different species: pedunculate oak (Quercus robur L.), sessile oak (Quercus petraea (Matt.) Liebl.), European beech (Fagus sylvatica L.), silver birch (Betula pendula Roth.), European larch (Larix decidua Mill.), Scots pine (Pinus sylvestris L.) and black alder (Alnus glutinosa (L.) Gaertn.). The highest survival rate $(100 \%)$ was observed in L1 and L2 larvae feeding on the roots of $P$. silvestris and $Q$. robur as well as in L3 larvae feeding on $Q$. petraea. The roots of $A$. glutinosa constituted the least beneficial diet for all the larval instars observed. The highest larval mortality was observed at molting into subsequent larval stages. L1 larvae showed the highest natural mortality.

\section{Biological means}

\section{Entomopathogenic fungi}

As already mentioned above, the fungus $B$. brongniartii infects cockchafer grubs under natural conditions. In Europe, attempts to control grub populations by means of this fungus were again made in the 1990s in Italy, Switzerland and Germany (Zimmerman 1992).
The possibility of control of cockchafer grubs in the soil was tested with the use of $B$. brongniartii infected cereal grain. In general, the results of numerous trials carried out under field conditions showed insufficient effectiveness of the treatments. The reasons of that were connected with fungus preparation quality as well as difficulties in introducing and blending infected grain with the soil, especially around young trees - where abundance of cockchafer grubs was expected. The trials carried out under field conditions in Switzerland, with the use of $25-100 \mathrm{~kg}$ of infected grain per hectare gave unsatisfactory results. In Germany, fungus treatment effectiveness was from $4 \%$ to $30 \%$ (Zimmerman 1992). The study carried out in Italy on relationships between dispersion of $B$. brongniartii in soils and grub infection with the fungus showed no significant results (Cravanzola et al. 1996). The Italian study included observations on fungus presence, grub population density and grub infection level. These were conducted in about 200 examination points. Grub numbers recorded in the soil tested were on average 9.7 specimens $/ \mathrm{m}^{2}$ soil $\left(1-72 \mathrm{sp} . / \mathrm{m}^{2}\right)$. In $78 \%$ of examination points, no presence of $B$. brongniartii was noted. In the group of approximately 2000 cockchafer grubs examined after the treatments, only 2 specimens were infected with the fungus. Statistical tests showed no relationship between $B$. brongniartii infection of $M$. melolontha larvae and dispersion of the fungus throughout soils (Cravanzola et al. 1996). The results of the study carried out in Switzerland (Keller et al. 1996) showed that better results on grub control were obtained by means of $B$. brongniartii infected barley grain sown into meadow soil when compared to orchards. The authors supposed that orchard soil properties could be a limiting factor for development of the fungus. In view of that, soil samples from both sites were collected, then 60 infected grains were introduced into each of them, and next the samples were incubated at $20^{\circ} \mathrm{C}$ for $15-17$ days. No statistically significant differences were found with reference to $B$. brongniartii development in the types of soil tested. In Germany, 26 B. brongniartii strains were analyzed under laboratory conditions with regard to their virulence against L2 and L3 M. hippocastani grubs (Trzebitzky 1996). After $48 \mathrm{~h}$ of incubation at $7^{\circ} \mathrm{C}$, there germinated only $10 \%$ of fungus spores, at $15^{\circ} \mathrm{C}$ - up to $15 \%$, and after $36 \mathrm{~h}$ of incubation at $25^{\circ} \mathrm{C}$, 
all fungus spores germinated. In this study, there were also tested different rates of fungus treatments; $10,10^{6}$ and $10^{7}$ spores $/ \mathrm{ml}$ were topically applied on cockchafer larvae $(0.1 \mathrm{ml} /$ larva). In 4 weeks of incubation at $19^{\circ} \mathrm{C}$, the concentration $10^{6}$ spores $/ \mathrm{ml}$ caused fungal infections in about $50 \%$ of examined grubs. After 90 days of incubation more than $90 \%$ of the grubs tested were infected with the fungus. The concentration $10^{7}$ spore $/ \mathrm{ml}$ resulted in $100 \%$ grub mortality due to fungal infection just in 4 weeks. The study included examination of $B$. brongniartii pathogenic activity against $M$. hippocastani adults and larval instars. Imagines and L1, L2 and L3 larvae were treated with the concentration $10^{6}$ spores $/ \mathrm{ml}$ and incubated for 90 days at $19^{\circ}$ C. B. brongniartii infestation was observed in $97.4 \%$ of adults examined and $96.6 \%$, $88.7 \%, 85.6 \%$ of L1, L2 and L3 larvae, respectively. The influence of soil reaction on germination of B. brongniartii conidia was studied by Sierpińska (2013), who showed no differences between several fungus strains regarding their ability to germinate either in acidic $(\mathrm{pH}=4)$ or neutral $(\mathrm{ph}=7)$ soils. On the other hand, in some strains there was observed 2-fold decrease of conidia germination in acidic soils. In general, under field conditions, grub population can be decreased to a harmless level by means of adequate fungus formulation, thoroughly mixed with soil and applied at sufficient weather conditions (in terms of air temperature and humidity). One time treatment during cockchafer life cycle is usually not sufficient to decrease grub population numbers. Cereal grain infected with $B$. brongniartii mycelium is the most often used type of fungal formulation applied with the use of a seeder (Malinowski 2010). Other formulation types include dry B. brongniartii hyphae or granulated mycelium. Nonetheless, B. brongniartii has not been authorized in the EU for use in commercial plant protection products, thus must not be applied as cockchafer control means (Malinowski 2010; Sierpińska 2013).

\section{Entomopathogenic bacteria}

In search for effective means to protect crops against cockchafer grubs, there has been also tested the possibility of utilization of pathogenic bacteria, such as e.g. milky disease-causing bacterium Bacillus popilliae var. melolonthae. German studies, undertaken under laboratory conditions, on the effectiveness of B. popilliae infection in cockchafer grubs fed on infected diet, showed no satisfactory results. However, disease incidence increased when the grubs were infected simultaneously with $B$. popilliae bacterium and $B$. brongniartii fungus, which could be attributable to some synergistic mechanism involved in pathogenic activity of the microorganism tested (Franken et al. 1996). The study on the effectiveness of bacteria from the genus Serratia against Melolontha hippocastani L2 and L3 instars was also carried out in Germany (Jackson and Zimmermann 1996). The results obtained indicated that several Serratia spp. isolates, derived from different insect species and served to the grubs as food with carrot roots, caused discontinuation of cockchafer larvae feeding. Other Serratia spp. isolates tested, including Serratia entomophila derived from the grass grub (Costelytra zealandica) showed no such effects.

\section{Entomopathogenic nematodes}

The option of utilization of nematodes to control population numbers of cockchafer grubs in the soil has been studied under field conditions. Entomopathogenic activity was shown in entomophilic nematodes from the orders: Steinernematidae - living symbiotically with bacteria Xenorhabditidae (Enterobacteriaceae) (Thomas and Poinar 1979) and Heterorhabditis (Heterorhabditidae) - living symbiotically with bacteria from the genus Photorhabdus (Boemare et al. 1993). Deseö et al. (1990) showed that sensitivity of $M$. melolontha grubs to entomopathogenic nematodes depended on pest larval instars; L1 and L2 grubs indicated the highest vulnerability to Steinernema glaseri and Heterorhabditis sp. Field trials on efficacy of Biovector preparation containing Steinernema carpocapsae nematodes carried out in Italy, resulted in 60\%-80\% mortality in M. melolontha grubs (in Sierpińska 2013). In 1994, there were carried out trials on control of other Scarabaeidae beetles Phyllophertha horticola L. and Aphodius sp. infesting golf fields in northern Germany with the use of nematodes $H$. megidis and $H$. bacteriophora at a rate 0.5 and 1.5 million of nematodes $/ \mathrm{m}^{2}$ soil (Ehlers and Sulistyanto 1996). In 42 days after application of $H$. megidis, mortality of Aphodius sp. was $40 \%$ and $53 \%$ for higher and lower nematode rate, respectively, and 29 days after application of $H$. baeteriophora - grub mortality was $55 \%$ and 
$62 \%$, respectively. A year after application, on the plots treated with $H$. bacteriophora, there was observed considerable reduction of Aphodius sp. population numbers, and on those treated with $H$. megidis no such effect was observed. The effectiveness of nematodes from the orders Steinernema and Heterorhabditis against cockchafer grubs was also investigated in Poland. The results of the study by Kowalska (2001) showed the reduction of L1 Melolontha spp. grub numbers in $P$. sylvestris reforested area (5-year-old) after treatments with $H$. megidis at a rate 100 larvae/ $\mathrm{cm}^{2}$. Kreft et al. (2012) applied nematodes Steinernema arenarium and Heterorhabditis megidis at a rate 50 and 150 million of nematodes per are and observed the reduction of grub numbers only for about two months after application.

\section{References}

Badeni. 1894. Główna rójka chrabąszcza majowego w 1894 roku. Sylwan. Czasopismo miesięczne dla leśników $i$ wtaścicieli ziemskich. Organ Galicyjskiego Towarzystwa Leśnego, 12, 132-134.

BB. 1892. Pasożyt chrabąszcza majowego. Sylwan. Czasopismo miesięczne dla leśników $i$ wtaścicieli ziemskich. Organ Galicyjskiego Towarzystwa Leśnego, 10, 362-364.

Boemare N.E., Akhurst R.J., Murant R.G. 1993. DNA relatedness between Xenorhabdus spp. (Enterobacteriaceae) symbiotic bacteria of entomopathogenic nematodes and a proposal to transfer Xenorhabdus luminescens to a new genus Photorhabdus gen. now. International Journal of Systematic Bacteriology, 43, 249-255.

Brenner H., Keller S. 1996. Protection of orchards from white grubs (Melolontha melolontha L.) by placements of nets. Integrated control of soil pests. IOBC/WPRS Bulletin, 19 (2), 79-82.

Cravanzola F., Piatti P., Ozino O.J., Bondaz F., Vallet S. 1996. Occurrence of the entomo-pathogenic fungus Beauveria brongniartii in the soil of Valle dAosta and investation level of Melolontha melolontha. Integrated control of soil pests. IOBC WPRS Bulletin, 19 (2), 59-64.
Deseö K.V., Bartocci R., Tartaglia A., Rovesti L. 1990. Entomopathogeneous nematodes for control of scarab larvae. IOBC/WPRS Bulletin, 14, 57-58.

Dominik J. 1954. Próba zwalczania trzyletniego pędraka chrabąszcza Melolontha melolontha L preparatem „Intox 8”. Sylwan, 3, 204-209.

Dominik J. 1958. Próba zwalczania dwuletniego pędraka chrabąszcza majowego (Melolontha melolontha L) przez dwukrotne traktowanie gleby preparatem „Intox 8”. Warsaw University of Life Sciences, Poland, 1, 77- 82.

Ehlers R.U., SuIistyanto D. 1996. Control of scarabaeid larvae in golf course turf with the entomogenous nematedes Heterorhabditis megidis and $H$. bacteriophora. IOBC/WPRS Bulletin, 19 (9), 84-85.

Franken E., Krieger L., Schnetter W. 1996. Bacillus popilliae: a difficult pathogen. Integrated control of soil pests. IOBC/WPRS Bulletin, 19 (2), 40-45.

Fröschle M. 1994. Der Feldmaikafer (Melolontha melolontha L.) muss in Baden Württemberg wieder ernst genommen werden. Nachrichtenblatt des Deutschen Pflanzenschutzdienstes, 46 (1), 6-9.

Głowacka B. 1996. Plant protection products recommended in forest protection in 1996. Forest Research Institute, Poland (in Polish).

Głowacka B. 2010. Plant protection products recommended in forest protection in 2011. Forest Research Institute, Poland (in Polish).

Głowacka B. 2011. Plant protection products recommended in forest protection in 2012. Forest Research Institute, Poland (in Polish).

Głowacka B.2012. Plant protection products recommended in forest protection in 2013. Forest Research Institute, Poland (in Polish).

Głowacka B. 2013. Środki ochrony roślin oraz produkty do rozkładu pni drzew leśnych zalecane do stosowania w leśnictwie w roku 2014. Instytut Badawczy Leśnictwa, Analizy i Raporty, 21.

Harborne J.B. 1997. Biochemical Ecology. Wydawnictwo Naukowe PWN, Warszawa, Polska (in Polish).

Hersy J. 1986. Detailed crop production. Państwowe Wydawnictwo Naukowe, Warszawa, Polska (in Polish).

Jackson T.A., Zimmermann G. 1996. In there a role for Serratia spp. in the biocontrol of Meolontha spp.? IOBC/WPRS Bulletin, 19 (2), 47-54. 
Janeczko M. 1906. O tępieniu szkodliwych owadów w szkółkach. Sylwan, 41-49.

Karpiński J.J. 1950. Zagadnienie walki z chrabąszczem za pomoca grzyba Beauveria densa Pic. Annales Universitatis Mariae Curie-Skłodowska, Sec. E, 2 , 29-68.

Keller S., Pärli B., Jacober C. 1996. The influence of soils on the growth of Beauveria brongniartii. IOBC/WPRS Bulletin, 19 (2), 74-78.

Kowalska J. 2001. An attempt to use entomopathogenic nematodes and integrated method in combating of Melolontha melolontha L. grubs in forest plantation. Sylwan, 2, 89-95 (in Polish with English summary).

Kreft A., Skrzypek H., Kazimierczak W. 2012. Entomopatogeniczne nicienie $\mathrm{w}$ ochronie roślin przed szkodnikami glebowymi. In: Kierunki rozwoju patologii owadów w Polsce (eds.: I. Skrzecz, A. Sierpińska), Instytut Badawczy Leśnictwa, Sękocin Stary, Polska, 270-278.

Malinowski H., Augustyniuk A., Łabanowska B.H. 2001. Nowe możliwości ograniczania populacji owadów żerujących na korzeniach roślin. Progress in Plant Protection, 41 (1), 175-181.

Malinowski H. 2003. Odporność owadów na insektycydy. Wydawnictwo Wieś Jutra, Warszawa, Polska.

Malinowski H. 2007. Aktualne problemy ochrony lasu związane ze zwalczaniem chrabąszczy (Melolontha spp.). Progress in Plant Protection, 47 (1), 314-322.

Malinowski H. 2009. Badania nad nowymi insektycydami do ochrony szkółek i upraw leśnych przed szkodnikami korzeni. Notatnik Naukowy IBL, 17 (3), 1-2.

Malinowski H. 2010. Niechemiczne metody ochrony szkółek i upraw leśnych przed owadami uszkadzającymi systemy korzeniowe drzew i krzewów. Instytut Badawczy Leśnictwa, Sękocin Stary, Polska.

Remiszewski K. 1899. Quo usque tandem Melolontha? Sylwan. Czasopismo miesięczne dla leśników i właścicieli ziemskich. Organ Galicyjskiego Towarzystwa Leśnego, 17, 136-141 (in Polish).

Różyński F. 1926. W sprawie walki z chrabąszczem majowym. Przeglad Leśniczy, 1, 32-38.

Satkowski K. 1899. Przyczynek do środków tępienia pędraków. Sylwan. Czasopismo miesięczne dla leśników i właścicieli ziemskich. Organ Galicyjskiego Towarzystwa Leśnego, 17, 52-54.
Schnaider Z., Karlikowski T. 1953. Z badań nad chemicznym zwalczaniem pędraków. Roczniki Nauk Leśnych, 4, 89-107.

Sierpińska A. 2013. Ocena wpływu wybranych czynników abiotycznych i biotycznych na efektywność porażenia pędraków chrabąszczy przez entomopatogeniczny grzyb Beauveria brongniartii (Sacc.) Petch. In: Bezpieczne dla środowiska metody ochrony ekosystemów leśnych zagrożonych przez chrabąszcze Melolontha spp. (ed.: L. Sukovata), Instytut Badawczy Leśnictwa, Sękocin Stary, Poland, 45-97.

Sierpiński Z. 1963. Jesienne zabezpieczanie upraw przed pędrakami za pomocą insektycydów. Prace IBL, 266, 52-62.

Sierpiński Z. 1975. Ważniejsze owady - szkodniki korzeni drzew i krzewów leśnych. Państwowe Wydawnictwo Rolnicze i Leśne, Warszawa, Polska.

Strasser H., Schinner F. 1996. Current status of Melolontha melolontha control by the fungus Beauveria brongniartii in Austria. IOBC/WPRS Bulletin, 19 (2), 69-73.

Śliwa E.1993. Szkodniki korzeni drzew i krzewów. Wydawnictwo Świat, Warszawa, Poland.

Thomas G.M., Poinar G.O. 1979. Xenorhabdus gen. nov., a genus of entomopathogenic and entomophilic bacteria of the family Enterobacteriaceae. International Journal of Systematic Bacteriology, 29, 352-360.

Trzebitzky C. 1996. Strain selection and epizootic features in microbial control with Beauveria brongniartii (Sacc.) Petch. IOBC/WPRS Bulletin, 19 (2), 54-58.

Ułatowicz W. 1932. Przykład walki z pędrakami. Echa Leśne, 132, 5-6.

Wospiel J. 1895. O szkodach wyrządzanych przez pędraki chrabąszcza majowego w lasach Łopatyńskich. Sylwan. Czasopismo miesięczne dla leśników i właścicieli ziemskich. Organ Galicyjskiego Towarzystwa Leśnego, 13, 89-92.

Woreta D. 1994. Zmiany występowania szkodników korzeni drzew i krzewów leśnych w latach 1961-1993. Sylwan, 5, 37-41.

Woreta D. 1995. Niepokojący wzrost znaczenia chrabąszczowatych w tym guniaka czerwczyka. Głos Lasu, 8, 13-15. 
Woreta D. 1997. Możliwości ograniczania szkód powodowanych przez pędraki chrabąszczowatych $(\mathrm{Me}$ lolonthinae) metodami niechemicznymi. Sylwan, 5 , 29-39.

Woreta D. 1999. Gradacja chrabąszczy w latach 1991-1998 oraz prognoza występowania w 1999 roku. Las Polski, 9, 24-25.

Woreta D. 2008. Chrabąszcze Melolontha. In: Krótkoterminowa prognoza występowania ważniejszych szkodników i chorób infekcyjnych drzew leśnych w Polsce w 2008 r. Instytut Badawczy Leśnictwa, Analizy i Raporty,10, 91-93.

Woreta D., Skrzecz I. 1996. Szkody wyrządzane przez owady w uprawach leśnych na gruntach porolnych i możliwości ich ograniczania. Postępy Techniki w Leśnictwie, 58, 34-42.

Woreta D., Sukovata L. 2014. Przeżywalność i wzrost pędraków Melolontha spp. na korzeniach głównych gatunków drzew leśnych. Leśne Prace Badawcze, 75 (4), 375-383. 